\title{
GTNP BREEDING BIRD MONITORING PROJECT: THE 2006 SEASON YEAR-TO-YEAR VARIATION IN AVIAN BREEDING DENSITIES IN GRAND TETON NATIONAL PARK
}

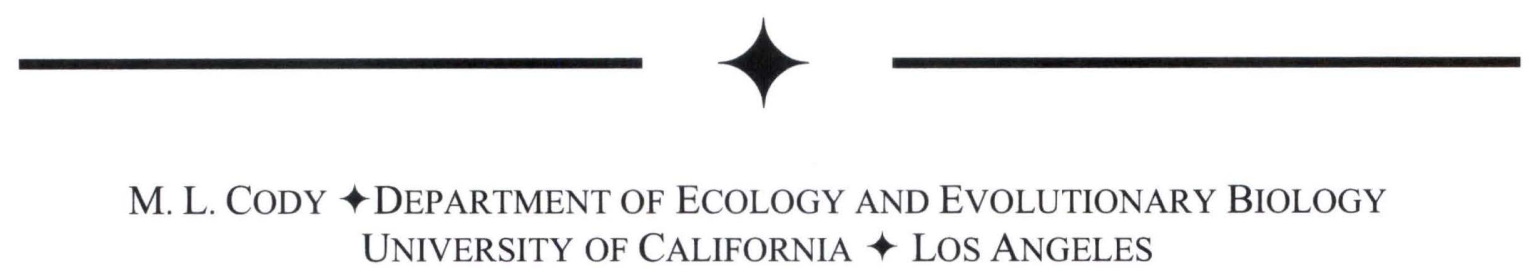

\section{$\downarrow \quad$ AbSTRACT}

Census work was carried out in midJune on 10 of the 30 breeding bird monitoring sites formally established in the mid 1990s. The censuses conducted in 2006 spanned a range of habitats from grassland and sage through willows and cottonwoods to pine and spruce-fir forest. Collectively, the sites cover all habitats within Grand Teton National Park, from lowest to highest elevations, and have produced records of 158 bird species since project initiation. Dry conditions prevailed in GTNP in late winter 2006 and extended into the spring and summer. Similarly, dry conditions were widespread in the overwintering areas of many of the migrants breeding within the park, from southern and southwestern USA south into northern and western Mexico.

The 2006 breeding birds showed overall lower densities, with especially low numbers in those species typical of wetland habitats. On the other hand, many species characteristic of drier habitats within the park and with geographic ranges extending south and west of the park were more common than usual. Comparisons are drawn, for different suites of birds, between 2006 densities and the long term average densities at the monitoring sites. Some attempt is made to distinguish between on-site and off-site influences on breeding bird densities, although these efforts remain tentative.

\section{$\downarrow \quad$ INTRODUCTION}

Monitoring of breeding bird densities in Grand Teton National Park has been ongoing in an organized fashion since the early 1990s, although data from some sites dates back a halfcentury (e.g. Salt 1957a,b; see overviews by Cody 1996, 1999, 2005). A suite of thirty monitoring sites was formalized in the mid1990s (Cody 1997). These sites, spread over the full range of habitats within the park, have been assessed for breeding birds with varying schedules; some sites have been evaluated yearly, continuously for the last 17 years, others have been visited more sporadically. The goals of continued monitoring efforts of the breeding birds are several fold: to assess long term trends and detect changes in breeding bird numbers, to evaluate any differences in breeding density variability between neotropical migrants and resident birds, and to record patterns of habitat use and variations of breeding densities over habitat gradients.

In 200610 monitoring sites were surveyed over $10 \mathrm{~d}$ in mid-June:

1. Site 2: Jackson Lake Junction (JLJ) Sedge Meadow

2. Site 4: JLJ Grass-sage

3. Site 5: Antelope Flats sage burn/nonburn

4. Site 9: RKO Dry Willows

5. Site 10: JLJ Wet Willows

6. Site 11: Oxbow Willow-aspen

7. Site 15: Spread Ck Cottonwoods 
8. Site 19: AMK Lodgepole Pine

9. Site 20: Taggart Lk Lodgepole Pine Burn

10. Site 25: Jenny Lk Spruce-fir

Bird census protocols followed those specified earlier for this project (e.g. Cody 1997). Each site is visited three times for several hours, at three different times of the day (early morning, late morning, afternoon). Bird activity records, movements, vocalizations and nesting are entered on a site map, from which estimates of territory numbers and breeding bird densities can be extracted.

Spring conditions in the northern part of Jackson Hole were dry (2006 April-June precipitation down $32 \%$ from the long-term average--LTA) and somewhat warmer than usual (cumulative mean monthly temperature up 3\% from LTA, and spring monthly maxima and minima were $2-3{ }^{\circ} \mathrm{C}$ higher than normal). Snowmelt date, the date by which snow no longer persists on the ground, at Jackson Lake Dam (NCDC climate station Moran 5 WNW; L. Robinson prop.) was close to average, namely Julian Date (JD) 116 (= April 22 $\left.{ }^{\text {nd }}.\right)$; cf. longterm average JD of snowmelt $=112 \pm 10$ SD. Winter conditions were dry also throughout the southwestern U.S. in early 2006 (NOAA-NCDC summaries) from Arizona to southern California, an area encompassing much of the wintering grounds for a number of GTNP breeding birds. In southern California NCDC stations from Santa Barbara to San Diego recorded collectively just $54 \%$ of their LTA precipitation. Further south in western Mexico, also an area that supports large wintering bird populations from the western U.S., including the central Rocky Mountains, there were winter drought conditions (NOAA web site). Weather stations (north to south over ca. $1400 \mathrm{~km}$ ) from Mazatlan SIN, Durango DGO, Tepic NAY, Cd. Guzmán JAL, Morelia $\mathrm{MICH}$ and Acapulco GRO recorded winter precipitation from November 2005 to March 2006 at or very near zero, although summer rainfall in the wettest months of August and September was at or above average at least in the southern part of this range.

\section{GTNP Bird Populations}

Censuses in 10 of the established monitoring sites produced several new site records and numerous shifts in density of individual species relative to previously tallied high and low values.
At Site 4, JLJ Grass-sage, Turkey Vulture (Cathartes aura) was a first for the site, and is a species that we have recorded with increased frequency over the last several years over the drier sage flats of Jackson Hole. Site 5 straddles the burned and unburned areas of the Antelope Flats, the Mormon Row fire of 1994. Now the species that utilized the burn in its early years (e.g. Long-billed Curlew Numenius americanus, Mourning Dove Zenaida macroura, Common Nighthawk Chordeiles minor, feeding Sage Grouse Centrocercus urophasianus) are long gone, and the $12 \mathrm{y}$-old recovering burn is mostly grassy and dominated by Savannah Sparrow Ammodramus sandwichensis, Vesper Sparrow Poocetes gramineus, and Western Meadowlark Sturnella neglecta. The unburned part of the plot is tall sage, and in 2006 supported a Sage Thrasher Oreoscoptes montanus for the first time.

Site 9, the RKO Dry Willows site, recorded its lowest ever densities of Common Yellowthroat Geothlypis trichas (1 pr; LTA 3.83 pr) and White-crowned Sparrow Zonotrichia leucophrys $(0.9 \mathrm{pr}$; LTA $=2.27 \mathrm{pr})$. In 2006 all three Spizella sparrows were recorded at the site (Chipping Sparrow S. passerina, Brewer's $S$. breweri, and Clay-colored S. pallida), although none is common there. 2006 was clearly a good year for Clay-colored Sparrows, as it was recorded at several sites; the species seems to be recovering from several decades of absence or great rarity, as it was relatively common in GTNP in the 1960s and 1970s. Site 10, the JLJ Wet Willows site, now has 17 y of continuous monitoring records. The site was drier than usual in 2006, with no rails or Marsh Wren Cistothorus palustris. The SW beaver pond was shrunken in size and just $3 \mathrm{pr}$ of duck, of three species, nested there (the norm is $6 \mathrm{pr}$ ). The $\mathrm{N}$ beaver pond, the dam being the northern boundary of the study site, supported a Northern Waterthrush Seiurus novaboracensis, but overall the number of locations within GTNP at which Northern Waterthrush can usually be heard singing was much reduced in this dry year. Pine siskins Spinus pinus utilized this site at high density from 2000-2005, following a major outbreak of a defoliating moth (of unknown providence, fide Dr. Clifford Ferris). The siskins foraged avidly on the pupating moths, whose cocoons were leaf-wrapped on the upper willow branches. The Oxbow willow-aspen, Site 11, continued the theme of scarcer wetland species and commoner "dryland" species, with the 
absence on Common Snipe Gallinago gallinago and presence of Lazuli Bunting Passerina amoena. The exceptional species at the site, however, was Gray Catbird Dumetella carolinensis, with $3 \mathrm{pr}$ in residence; the LTA for the species at this site is $0.72 \mathrm{pr}$, and the previous density high was just a single pair.

The cottonwood census at Site 15, Spread Creek, again reflected the overall conditions of the year, with dryland species Clay-colored Sparrow and Common Nighthawk present, and species with a preference for a more mesic lower stratum of vegetation, the two usual hummingbird species, Fox Sparrow Melospiza iliaca, and White-crowned Sparrow absent or nearly so. Moving to the pines, Site 19, AMK Lodgepole Forest, the commonest species here is Dark-eyed Junco Junco hyemalis, slightly over 1 $\mathrm{pr} / \mathrm{ha}$. In 2006 the numbers were at a hitherto unrecorded low of $5 \mathrm{pr}$ (LTA $6.5 \mathrm{pr}$, max. 8pr). The second commonest species here is Yellowrumped Warbler, at it also was at somewhat lower than usual density.

The 1985 lodgepole pine burn at Taggart Lake has been followed via the monitoring site there. Many of the species that depended on the standing dead snags for nest sites, species common 1994-2001, are now gone, since the standing dead are nearly all fallen. The list includes Mountain Bluebird Sialia curruca, House Wren Troglodytes aedon, Violet-green and Tree Swallows (Tachycineta thalassina, $T$. bicolor). The lodgepole regrowth is vigorous but patchy, with some of the seed-sprouted stems $6+$ $\mathrm{m}$ tall. New species have invaded with post-fire recovery, with the advent of Swainson's Thrush in 1996, followed by Western Tanager Piranga ludoviciana, Yellow-rumped Warbler Dendroica coronata and Warbling Vireo Vireo gilvus in 1997. Many of the typical lodgepole pine forest, however, have yet to reappear after 22 y: Redbreasted Nuthatch Sitta canadensis, Brown Creeper Certhia americana, Cassin's Finch Carpodacus cassinii, Mountain Chickadee Parus gambeli.

The last site of those censused in 2006 is Site 25: Jenny Lake Spruce-Fir. This site burned $9 / 2 / 99$, some 5 y after it was established as a monitoring site. Post-fire around two-thirds of the canopy was gone, and most of the shrubs layers below it. Species recorded post-fire but not pre-fire include Downy, Black-backed and Three-toed Woodpeckers (Picoides pubescens,
$P$. arcticus, $P$. tridactylus). Least Flycatcher Empidonax minimus, Tree and Violet-green Swallows, House Wren, Mountain Bluebird, Cedar Waxwing Bombycilla cedrorum, Lazuli Bunting, Green-tailed Towhee Pipilo chlorurus, Lincoln's Sparrow Melospiza lincolnii and White-crowned Sparrow. Species recorded prior to the burn but not since include Blue Grouse Dendragapus obscurus, Great-horned Owl Bubo virginianus, Golden-crowned Kinglet Regulus satrapa, Hermit Thrush Catharus guttatus, White-winged Crossbill Loxia leucoptera. Most species present pre-burn persisted afterward, but many at reduced densities. Brown Creeper has recently recolonized the site. In 2006 Western Wood Pewees Contopus sordidulus and Hammond's Flycatchers Empidonax hammondii were unusually common, while Red-breasted Nuthatch, Western Tanager and Red Crossbill Loxia curvirostra, which persisted after the fire, were all absent (and Mountain Chickadee nearly so). As at Site 19, both Dark-eyed Junco and Yellow-rumped Warbler were much rarer than usual (2.5 pr vs LTA $3.7 \mathrm{pr}$, and $1.25 \mathrm{pr}$ vs LTA $4.9 \mathrm{pr}$ respectively).

\section{Deviations from Long Term Densities}

The time-spans over which breeding bird census activities have been pursued at the monitoring sites vary from 7-17 y in the modern era (n.b. some sites were censused by the author and others in the 1960s and 1970s, and one site [\#10] even in the 1950s). This permits comparison of 2006 densities with LTA densities at some 10 sites over a range of habitat types. The results of these comparisons are shown in Figs. 1-4. Species are included in these comparisons if they are present at sites in $>50 \%$ of the census years, and are relatively common (and so more easily censused accurately) within census years.

In Fig. 1 are data for three species of wetland species, more definitively so in the case of the first two (Fig. 1A: Common Snipe, Fig. 1B: Common Yellowthroat), less so in the third (Fig. 1C: Fox Sparrow). In the first two, densities are zero or very low in all habitats except the wettest (Site 10), where they are up very slightly. Fox Sparrow is somewhat scarcer than LTA density in three sites $(9,10,11)$. The lower parts of each of the figures give the deviation of 2006 from long term density in terms of standard deviation (SD) units, as a means of gauging the relative significance of the 
observed deviation. It appears likely that these wetland species are recorded at reduced densities in 2006 because the monitoring sites are drier and constitute less suitable habitat.
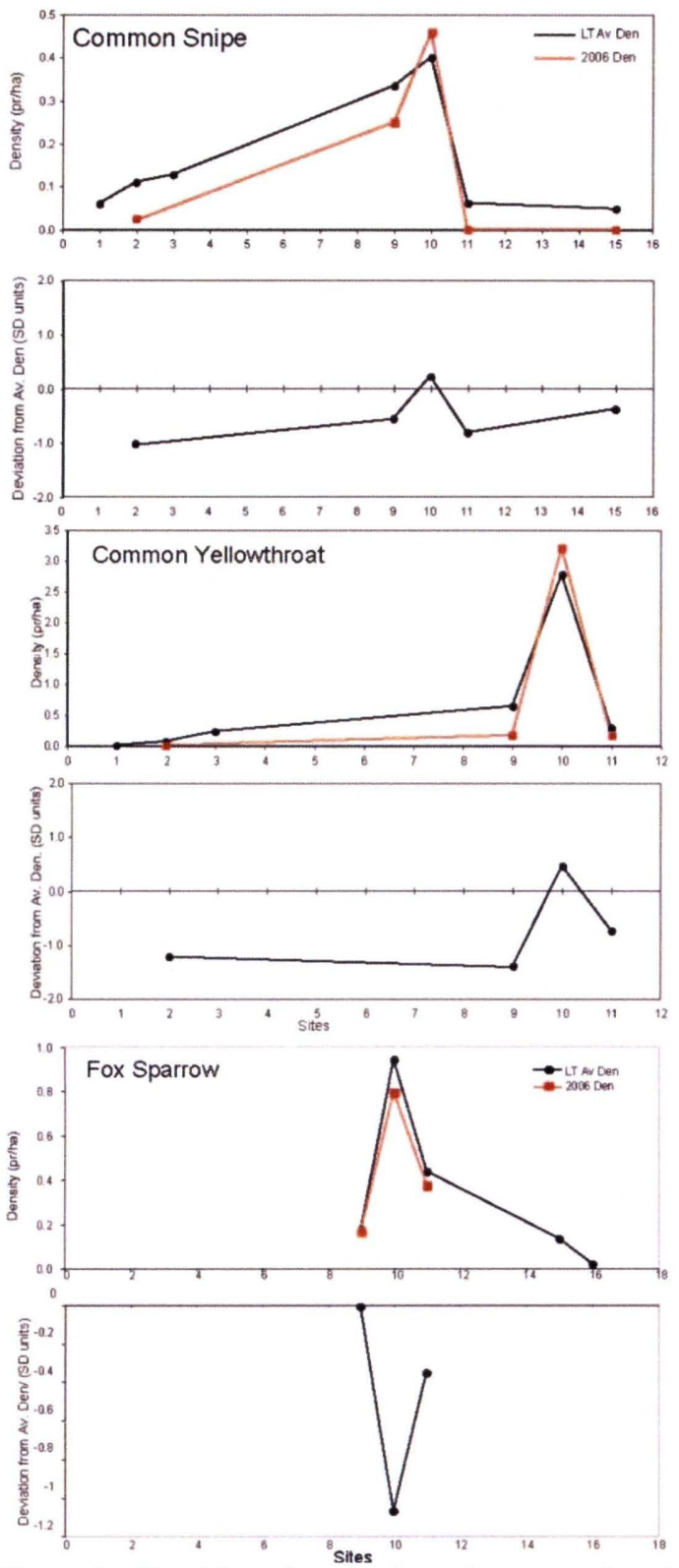

Figure 1. Densities of wetland species at monitored sites in 2006, 1A is the Common Snipe (5 sites), 1B is the Common Yellowthroat (4 sites), and $1 \mathrm{C}$ is the Fox Sparrow (3 sites).
Three broad-ranging species are depicted in Fig. 2. American Robin (Turdus migratorius; Fig. 2A) has a broad North American range, occupies a wide range of habitats in GTNP, and is a local to short distance migrant. Its 2006 GTNP densities are not dramatically different from LTA densities across the board. The same might be said for Yellow Warbler (Dendroica petechia; Fig. 2B), with similar broad ranges across geography and local habitats. It also occupied sites at more or less normal densities, although it is one of the farthest migrants amongst the GTNP breeding birds, reaching NW South America. The third species in the figure, White-crowned Sparrow (Fig. 2C), shows a very different pattern; the species was conspicuously sparse over all of its usual breeding sites, from sagebrush to willows to lodgepole forest, with dramatic (and statistically significant) density declines. The species winters in the SW USA, utilizing shrub and scrublands from California to Texas and into north-central Mexico. These are the regions most affected by the paucity of winter rainfall 2005-6, and it seems likely that the reduced densities of these species in GTNP is attributable not to a reduction in local habitat quality (and certainly not across all habitats), but to poor overwinter survival.

Some breeding species in GTNP are characteristic of generally more arid habitats and regions, such as the Great Basin sagebrushdominated Desert (Brewer's Sparrow, Fig. 3A), open pine woods, edge and scrub continent-wide (Chipping Sparrow, Fig. 3B), or the mixed conifer and especially oak woodlands of the SW USA south to central Mexico (Warbling Vireo, Fig. 3C). All three of these species show density increases in 2006. Notably, the density increase in Brewer's Sparrow is most apparent in its preferred sagebrush habitat (Site 4), that in Chipping Sparrow most prominent in its preferred conifer habitats (Sites 19-25). Warbling Vireo also shows the larger density shifts in conifers (rather, e.g. than cottonwoods Site 15). It might well be that the effects of drier on-site conditions have negatively impacted broad-leafed vegetation more than the needleleaved sites. However, this, if it occurs, is not reflected in overall bird densities, which were down $5 \%$ in both broad-leaved and needle=leaved vegetation in 2006 . 

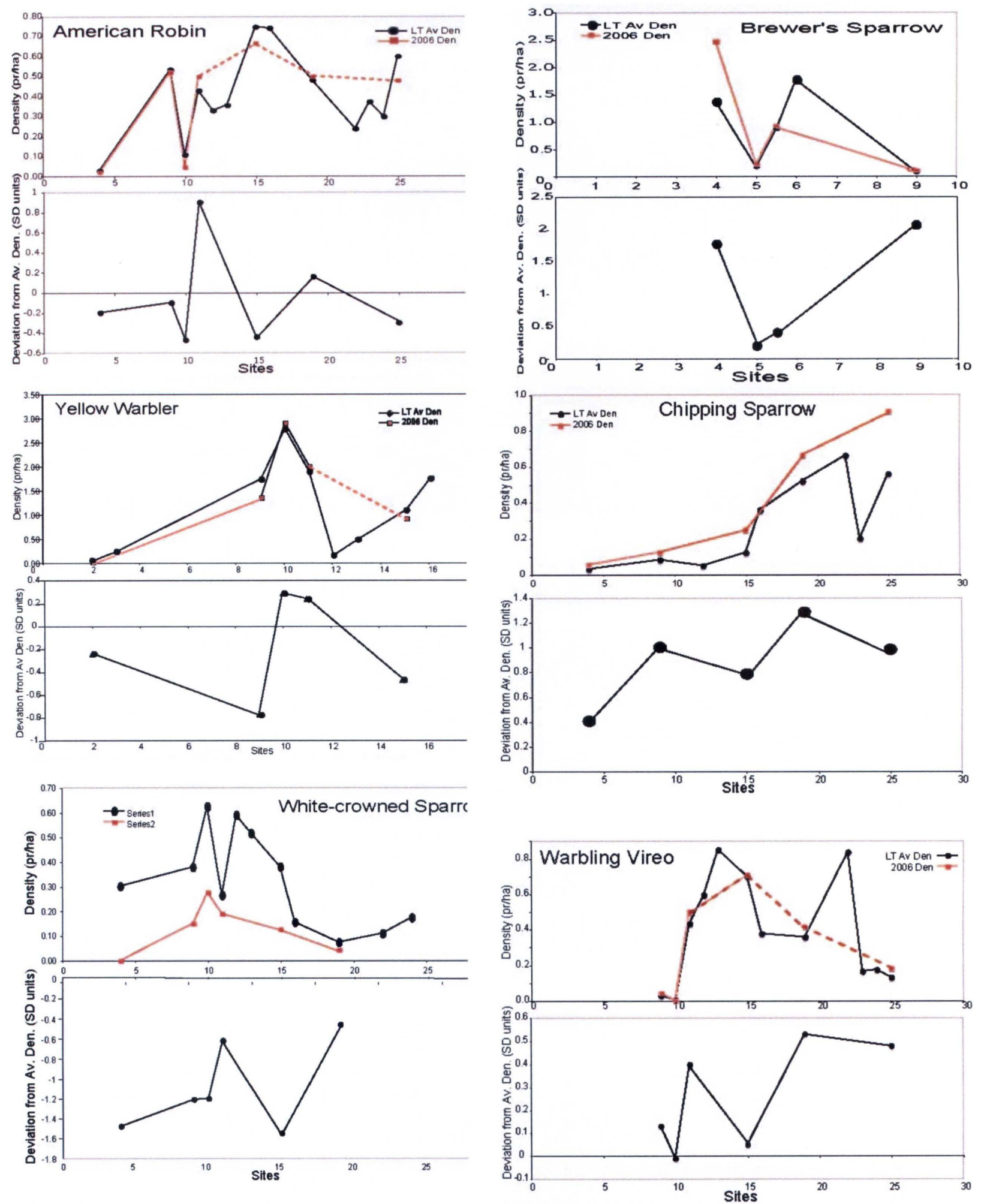

Figure 2. Densities of broad ranging species at monitored sites in 2006. 2A is the American Robin (7 sites), $2 \mathrm{~B}$ is the Yellow Warbler (5 sites), and $2 \mathrm{C}$ is the White-crowned Sparrow (11 sites).

Figure 3. Densities of desert and sagebrush dwelling species at monitored sites in 2006, 3A is the Brewer's Sparrow (4 sites), 3B is the Chipping Sparrow ( 9 sites), and $3 \mathrm{C}$ is the Warbling Vireo (11 sites). 
Fig. 4 depicts data from three species whose preferred habitat is the conifer forests. In Fig. 4A Western Wood Pewee apparently had a very good summer in GTNP in 2006, with densities well above average and especially high in its preferred conifer forest habitats. This species also is a long distance migrant, and winters in South America; thus it may have escaped to poor wintering conditions likely suffered by species within SW North America. Yellow-rumped Warbler has a similar range of occupied habitats as the pewee (Fig. 4B), but its 2-006 densities show a very different pattern: it bred at lower than usual densities across the habitat range, and especially in the taller conifers. Unlike the pewee, this warbler winters further north than almost any other paruline, and it is a particularly common winter bird in southern California, throughout the southwest and into northern and central Mexico. Thus it likely experienced poor overwintering conditions due to unusual aridity, and its lowered densities in GTNP seem better ascribed to this rather than depletion in local habitat quality. Lastly, Fig. 4C shows Dark-eyed Junco, which occurred in its GTNP sites at reduced densities in 2006. Juncos were most common in their preferred pine habitats, far less common in the more marginal (for them) cottonwoods. This again, like the warbler, is a short-distance migrant, with some juncos wintering throughout the Rocky Mountain foothills as far north as the central Rockies and even Jackson Hole. Low junco densities in the cottonwoods (Site 15) might be attributable to the dry spring, perhaps an important factor in the life of these phreatophytes, or alternatively to poor survival of the winter. It is likely that these alternatives might be readily distinguished if measures of productivity in local GTNP habitats were part of the monitoring scheme.
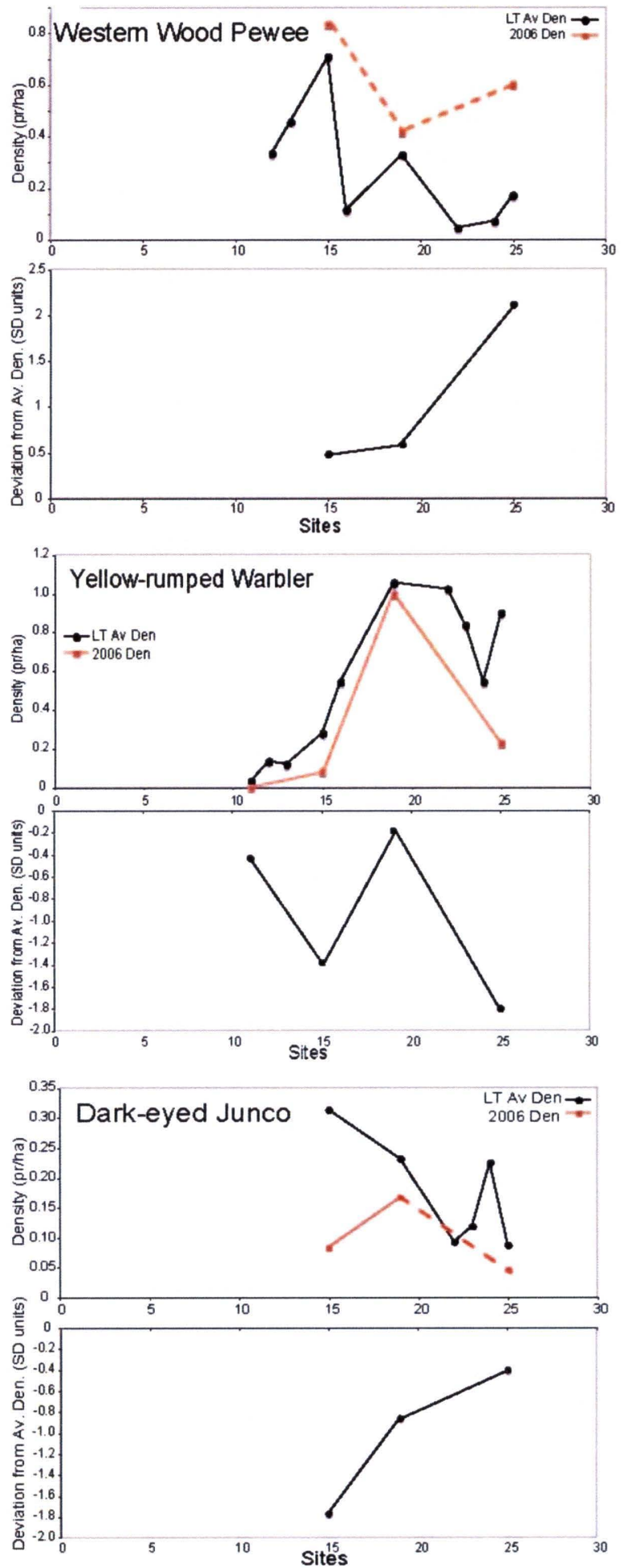

Figure 4. Densities of species that prefer conifer habitat at monitored sites in 2006, 4A is the Western Wood Peewee ( 8 sites), $4 \mathrm{~B}$ is the Yellow-rumped Warbler (10 sites), and $4 \mathrm{C}$ is the Dark-eyed Junco (6 sites). 


\section{$\downarrow$ ACKNOWLEDGEMENTS}

Thanks to the many birdwatchers who have contributed in the past to the monitoring project which, while it gains credence and power each year with additional data, lacks the personpower to make a comprehensive annual count at each site. Prof. H. Harlow kindly made available the wonderful facilities of the National Park Service Research Station at the AMK Ranch for the duration of the field work.

\section{$\downarrow$ Literature Cited}

Cody, M.L. 1996. Bird communities in the central Rocky Mountains. Ch. 11, pp. 291-342 in Cody, M. L. \& J. A. Smallwood, Long-Term Studies of Vertebrate Communities. Academic Press, Orlando, FL.

Cody, M.L. 1997. Monitoring Bird Populations in Grand Teton National Park. Final Report, National Park Service. v.1,2.
Cody, M. L. 1999. Assembly rules at different scales in plant and bird communities. Ch. 6, pp. 165-205 in Weiher, E., \& P. Keddy (eds.), Ecological Assembly Rules. Cambridge Univ. Press, Cambridge, UK.

Cody, M. L. 2005. Seasonal bird traffic between Grand Teton National Park and western Mexico. Pp. 32-43 in Ralph, C. J. \& Rich, T. D. (eds.), Bird Conservation, Implementation and Integration in the Americas: Proceedings of the Third International Partners in Flight Conference. V.1. Gen. Tech Paper PSW-GTR-191, Pac. SW Res. Stn., USDA Forest Service, Washington, DC.

NOAA World Climate Summaries: http://www7.ncdc.noaa.gov/IPS/MCD $\underline{\text { WPubs }}$

Salt, G. W. 1957a. An analysis of avifaunas in the Teton Mountains and Jackson Hole, Wyoming. Condor 59: 373-393.

Salt, G. W. 1957b. Song, Lincoln's, and fox sparrows in a Tetons willow thicket. Auk 74: 258 